Article

\title{
Eco-nomics: Are the Planet-Unfriendly Features of Capitalism Barriers to Sustainability?
}

\section{Merrill Singer ${ }^{1,2}$}

1 Center for Health, Intervention and Prevention (CHIP), University of Connecticut, Storrs, CT 06269, USA; E-Mail: Merrill.Singer@Uconn.edu; Tel.: +1-860-593-5249; Fax: +1-860-480-1719.

2 Department of Anthropology, University of Connecticut, Storrs, CT 06269, USA

Received: 1 December 2009 / Accepted: 4 January 2010 / Published: 6 January 2010

\begin{abstract}
This paper argues that there are essential features of capitalist modes of production, consumption, and waste dispersal in interaction with the environment and its built-in systemic features that contradict long-term sustainable development. These features include: (a) contradictions in the origin and meaning of sustainability; (b) the central role of the productivity ethic in capitalism and its reproduction in emergent green capitalism; (c) the commodification of nature and the continued promotion of expanding consumption; (d) globalism and the contradictions of continued Western-style development; and (e) the emergence of anthropogenic ecocrises and crises interaction. In light of these barriers to capitalist sustainability, an alternative social narrative is needed, one that embraces values, understandings, and relationships that promote ecological stability and justice.
\end{abstract}

Keywords: sustainability; development; capitalist modes of production; environmental degradation; barriers to sustainable development; pluralea

Ecocide is by far the greatest threat to the security of every being on planet Earth.

Leslie Sponsel, 2007

\section{Introduction}

In March 2008, the Wall Street Journal hosted the first of what may become an annual series of "CEO-Level" conferences on "the relationship between the environment and the bottom line." Entitled ECO:nomics: Creating Environmental Capital, the venue for the top-drawer gathering was a 78 acre, 
luxury resort and spa overlooking the Pacific Ocean (with penthouse rooms at $\$ 2,500 /$ night), in scenic Santa Barbara, California. While the deep eco-footprint of such an opulent hotel (designed to "evoke the gentility and glamour of the golden age of Hollywood" and described by one visitor as having "the perfect amount of hedonism") would appear to contradict even green capital's sustainability narrative, the contemporary need for an "eco-nomic" assessment is undisputed. Working from a rather different future imaginary than green capitalism - one that is informed by a political ecology of health perspective [1] - my objective in this paper is to examine inherent economic, environmental, and social features of capitalism that loom as significant barriers to sustainability. Specifically, I address the following "conundrums of capitalism" in an era of mounting levels of environmental degradation:

(a) contradictions in the origin and meaning of sustainability;

(b) the central role of the productivity ethic in capitalism and its reproduction in green capitalism;

(c) the capitalist commodification of nature and the continued promotion of expanding consumption;

(d) globalism and the contradictions of continued Western-style development; and

(e) ecocrises and crises interactions.

As conclusion to this analysis, which, unlike the aforementioned conference, is concerned with sustaining Earth and its inhabitants rather than capitalism and its profits, I argue for the need for an eco-nomic transcendence of the capitalist mode of production. While popular pressure can produce short-term and usually local gains in limiting the environmental effects of one or more of the environmental contradictions of capitalism, eliminating them all in the struggle for sustainability requires an alternative social narrative. One such alternative is based on the work of a number of scholar/activists who wed ecological sustainability and social equity.

\section{Sustainability: Conceptual Disputations}

As Castro [2] stresses, "the concept of sustainable development has become one of the most ubiquitous, contested, and indispensable concepts of our time." The reasons for controversy in the sustainability discourse merit attention as they point to some of the key issues of concern to this paper. As Castro points out, the concept of sustainability did not grow directly out of the conservation or environmental movements per se, but rather developed in response to the emergence of several decades of the limits-to-growth literature. This body of work, which certainly was influenced and made possible by the conservation and environmental movements, began to appear in 1954, ushered in by the publication of Harrison Brown's The Challenge of Man's Future [3], a book that argued that the full development of all countries of the world to the level that had been achieved in the West would lead to a total collapse of Earth's natural resource base. While Harrison's book and the ideas it expressed were largely ignored in the initial years after their appearance, in the 1960s the influential British economists Barbara Mary Ward and Kenneth Boulding independently began to advocate for sustainable development and for an end to treating the planet as a bottomless waste bin. Notably, in her writings, Ward employed the term "inner limits" to refer to the human right to an adequate standard of living and "outer limits" to suggest there were boundaries on what the planet could sustain. Similar ideas, and the concept of "spaceship earth," the title of one of Ward's books and a theme of a widely 
read paper by Boulding, were adopted by visionary designer R. Buckminster Fuller, who believed that the diverse inhabitants of Earth must function together as a integrated crew if we are to survive together on this planet.

In 1972, almost two decades after Brown's book was published, the Club of Rome issued a similar volume entitled The Limits to Growth. Combining the work of an international and multidisciplinary team of experts, the book projected a global economic collapse some time before $2100 \mathrm{AD}$ as a result of the calculable limits of the environment to both provide the natural resources needed to meet rising global levels of consumption and endure the resulting waste of ever-expanding production [4]. While committed to market-based economics, the Club of Rome recognized the challenges industrial capitalism presents to maintaining the ecosystems on which all life on the planet depends. Despite its dire warnings, The Limits to Growth did not lead to changes in what Baer has termed "the capitalist treadmill of production and consumption" [5]. Consequently, in 1992 the Club of Rome [6] released a follow-up study entitled Beyond the Limits: Confronting Global Collapse, Envisioning a Sustainable Future. Using new data, the book somberly affirmed the grim conclusions of the Club's initial report. As stressed at its 2009 International Conference on Concerted Strategies to Meet the Environmental and Economic Challenges of the 21st Century, which was convened as part of the preparatory process for the Copenhagen Conference on a post-Kyoto Treaty, the Club of Rome views the starting point of sustainable development as being the formulation of "new measurements for growth that place a real economic value on our natural capital, including carbon, water, forests, biodiversity and our marine environment. This will ensure that the real costs of environmental degradation are reflected in economic decision-making" [7].

Prompted by the original Club of Rome publication, in 1977 U.S. President Jimmy Carter commissioned his own study of global population changes, resource availability, and adverse environmental trends. While much more narrowly conceived than the analysis undertaken by the Club of Rome, the resulting Global 2000 Report to the President of the United States [8] included its own dire warnings about approaching environmental crises: "If present trends continue, the world of 2000 will be more crowded, more polluted, less stable ecologically, and more vulnerable to disruption than the world we live in now. Serious stresses involving population, resources, and environment are clearly ahead" [8]. A year after this initial report, a follow-up and more urgent document, entitled Global Future: Time to Act [9], was released with the intention of sparking public discussion of recommendations for imperative action.

In response to this disturbing set of increasingly well publicized reports that uniformly concluded the solemn adverse effects of accelerating environmental deterioration on social and economic development, the United Nations General Assembly created the World Commission on Environment and Development in 1983. Soon known as the Brundtland Commission, after its chair, Norway's Prime Minister Gro Harlem Brundtland. The Commission's report, entitled Our Common Future, repeated the general limits-to-growth perspective and proposed an alternative path which it called sustainable development. This was defined as development that "meets the needs of the present without compromising the ability of future generations to meet theirs" [10]. What this meant in practical terms was revealed in the report as "more rapid economic growth in both industrial and developing countries, freer market access for the products of developing countries, lower interest rates, 
greater technological transfer, and significantly larger capital flows, both concessional and commercial [10].

This neoliberal business-as-usual approach to development was subsequently popularized at the Earth Summit held in Rio De Janeiro, Brazil in 1992 and the subsequent issuance of Agenda 21, a call for sustainable development, as the tidy solution to the grave threats to the planet detailed in the limits-to-growth literature as well as the growing number of reports beginning to appear on global climate change [11]. According to Agenda 21, sustainability flows from the use by multinational corporations of an environmentally pegged pricing structure for goods and services: "A positive contribution of business and industry, including transnational corporations, to sustainable development can increasingly be achieved by using economic instruments such as free market mechanisms in which the prices of goods and services should increasingly reflect the environmental costs of their input, production, use, recycling, and disposal subject to country-specific conditions" [11].

Meanwhile, the anthropogenic greenhouse gases that propel global warming were continuing to build in Earth's atmosphere, although this did not immediately impact the limits-to-growth discourse or international discussions of mounting environmental threats to the achievement of a brighter global future. Nevertheless, throughout this period, a small but growing number of climate, glacial, oceanic and other scientists began to record signs of a significant and potentially consequential shift in Earth's temperature patterns. The United Nation's Intergovernmental Panel on Climate Change (IPCC), a body composed of approximately 2,500 climate and other scientists from around the world, issued its initial report on these changes in 1990 [12]. This document projected that by the year 2100 there would be an average global temperature rise of about $3^{\circ} \mathrm{C}$ if then current rates of greenhouse gas emissions continued. These rates, in fact, rose in the aftermath of the initial report as well as a subsequent series of increasingly more pointed IPCC reports warning of pending environmental danger. These documents were featured at the Rio Earth Summit in 1992 and attracted an ever growing level of attention in the following years.

Ultimately, most scientists involved in this research initiative concluded that the world was becoming a place of melting glaciers, rising seas, increasing numbers of droughts and heat waves, ever more violent storms, more frequent wild fires, and spreading environment-linked diseases. Early in the 21st century, a study undertaken by the World Health Organization [13] concluded that over 150,000 people a year were already dying from the effects of global warming and predicted a doubling of this number by the year 2020, if not sooner. In response to the mounting evidence of global warming, Emilio Moran, an internationally known scholar and IPCC member, raised a number of critical questions:'Do we recognize that business-as-usual threatens the end of life as we know it? Are we willing to use the considerable mental capacity, and exercise our political will, to ensure our survival and that of our children? Or are we so self-satisfied in our own material success that we cannot recognize overwhelming evidence when we see it?" [14]

While organized denial of global warming - some of which is funded by major multinational polluting corporations - and very slow governmental response followed in the wake of the IPCC reports [1], one notable consequence of the increasing publicity about and awareness of global warming was the emergence of sustainability as a topic of broad government, media, and popular concern. 
As this review suggests, decades characterized by mounting evidence of impending environmental peril and increasingly certain signs of an ever accelerated pacing of this process, slipped by with only limited effort to take corrective action. To a large degree, an ideology of denial and delay prevailed, especially in the United States but elsewhere as well. Even today, at this late date in scientific awareness of emergent ecocrises, Lord Drayson, Minister for Science and Innovation of the United Kingdom points out: "There is a significant minority of senior [corporate] managers who do not accept the evidence for climate change and don't see the need to take action.... The industrialists are faced with a very difficult challenge, which is huge infrastructure investment in existing ways of doing business and very difficult global economic circumstances... The temptation is to say we'll get round to dealing with climate change once we've fixed all this other stuff" [15].

Moreover, it is evident that the concept of sustainability did not initially emerge out of popular movements to protect the environment but rather as a fallback economic solution to the growing although still far from uniform recognition that unbridled growth and unchecked development on a global scale would ultimately lead to ecological disaster and economic collapse. As originally conceived, sustainable growth would be achieved through neoliberal market mechanisms supplemented by recycling and other conservation measures. Sustainable development, in this view, did not mean a radical break with past practices but rather a continuance of prevailing capitalist patterns in a modified form that included components designed to replace (some) extracted resources, re-use materials (if possible), and exploit renewable (or at least seemingly renewable) energy sources [16,17].

Also imbedded in the early sustainable development model was the notion that extension of the market and free trade would help to curb poverty in developing nations, which, in turn, would eliminate one of the important causes of environmental degradation, growing world population. The issues of empowerment and popular involvement in sustainable development decision-making were not part of the modified development strategy any more than they had been part of the original approach of holding up developed countries as models for the development of Third World countries.

Ultimately, of course, once the rise of scientific evidence had sufficiently weakened denial of global climate change, alternative perspectives on sustainability emerged, including those that, contrary to the corporate view, do not see sustainability as meaning sustained growth and continued economic expansion but rather the prioritization of a healthy planet and healthy human and other populations that share our planet [18].

\section{Centrality of the Productivity Ethic in Capitalism and Its Reproduction in Green Capitalism}

Views of development that emerge from mainstream economics are colored by a perspective of the world that embraces a powerful, capitalistic, "productivist ethic." This term refers to the belief that constant economic expansion is a necessary and inescapable component of capitalist economy, that such growth is socially beneficial for rich and poor alike, and that left unfettered it will produce solutions to societal problems of inequality and environmental degradation. The devotion of those, including leading capitalist economists, who embrace this perspective led the economically trained environmentalist Clive Hamilton [19] to suggest that capitalism is characterized by an economic 
"growth fetish" that parallels the religious dichotomy between heaven and hell and dictates that there are only two economic options: grow or collapse.

Signs of this fetish abound. The total value of global commodities continues to rise, at a rapid pace, growing 100 times between 1948 and 2000, when it set a new high of \$6 trillion. By 2008, this figure had climbed to $\$ 10$ trillion. Over the 30 year period from 1970 to 2000, the world's Gross Domestic Product (GDP) (measured in constant 1995 dollars), a tally of the market value of all final goods and services produced, nearly tripled, rising from \$13.4 trillion to \$34.1 trillion. During the next five years it expanded more than any period since the end of the Second World War [20]. Notably, the GDP is harnessed to explicit economic transactions and hence its use skews accounting away from including several kinds of production. A good example of this is provided by Zencey [21] who notes that "If you let the sun dry your clothes, the service is free and doesn't show up in our domestic product; if you throw your laundry in the dryer, you burn fossil fuel, increase your carbon footprint, make the economy more unsustainable - and give G.D.P. a bit of a bump." Despite the shortcomings of this indicator and its built-in tendency to stress the value of societal extractions from nature over often hidden sustainable exchanges with it, the GDP provides a rough sense of the "success" of the productivist ethic at the heart of capitalism. As stressed by Gellner [22], capitalist society "is the only society ever to live by and rely on sustained and perpetual growth." Moreover, explains Robbins [23], when economists working within a capitalist framework use the term growth what they mean is "that each of us, on average, must produce and spend 3-5\% more this year than last year, and 3\%-5\% more next year than this, in perpetuity." This process entails the continual, ever accelerating, transformation of activities (e.g., services) and materials extracted from nature into saleable commodities. Also inherent in this process, through production, transportation, and consumption, is the creation of waste, especially industrial effluent and agrochemical runoff (often treated as an external factor that is not incorporated into capitalist economic models), which is returned in some fashion, often detrimentally, to the environment.

Recognition of some of the problems inherent in this "resource warehouse/waste dumping ground" approach to the environment, that is "its treatment of external habitats as a vast commons" [24], led to a degree of rethinking within the framework of conventional capitalist perspectives. This has entailed the development of various technical sustainability fixes intended to allow things to change just enough to avoid sweeping transformations in the social relations of production (e.g., recycling programs and industries, government subsidies for green technologies, cap and trade policies) coupled with individual lifestyle changes designed to reduce the size of one's ecological footprint (e.g., replacing incandescent bulbs with compact fluorescent bulbs, installing a programmable thermostat, keeping furnace and air conditioner filters clean, buying energy efficient appliances, installing double glazed windows) [25].

Additionally, some corporations have "gone green" and begun to support a program of (limited) action to reduce global warming (while still promoting the expansion of production and consumption). At the heart of this development, a component of which has been called the corporate social responsibility movement, is the belief that capitalism can be built on a mixed foundation comprised of ecological sustainability and economic self-interest. Many industries now have voluntary codes of conduct (e.g., the Responsible Care Code of the chemical industry) and claim that one of their missions is to inform consumers about green products. On the whole, these approaches skirt addressing 
the finite nature of global resources, the global inequality and poverty that stem from unequal access to natural resources, and the role of poverty in population growth and resulting increases in resource needs. Some corporations are beginning to partner with environmentalist groups to promote certain publicity worthy environmental causes, although uniformly these projects focus on limited and incremental rather than sweeping, crisis-driven environmental initiatives.

An early example of this direction was undertaken by British Petroleum (BP) in the late 1990s when the company decided to reduce its emissions of greenhouse gases, especially carbon dioxide. The program cost BP about $\$ 20$ million dollars but it led to corporate saving of over $\$ 2$ billion. According to BP Chief Executive, Lord John Browne, "We set out to do good.... and ended up doing well" [26]. This case is touted by Esty and Winston in their book Green to Gold: How Smart Companies Use Environmental Strategy to Innovate, Create Value, and Build Competitive Advantage as a model for other corporations to follow. But, as they make clear, the ultimate rationale is not protecting the environment because: "The logic of corporate environmental stewardship need not stem from a personal belief that caring for the natural world is the right thing to do. If critical stakeholders believe the environment matters, then it's the right thing to do for your business [26]. As an example, they cite the case of Toyota's Prius automobile. Although this hybrid passenger vehicle is widely held up as a model of corporate responsibility in reducing automobile gas consumption, in fact the nickel and other metals used in constructing the car's battery are mined by methods that are decidedly not eco-friendly. But, argue Esty and Winston, this is irrelevant because what matters in the marketplace is the public perception that the Prius is an eco-friendly vehicle. As this example suggests, a fundamental question for green capitalism in its various expressions is this: does this approach to production and consumption seek to solve anthropogenic ecocrises or profit from them (i.e., what has been termed sustainable prosperity)?

Promoters of green capitalism stress that it is really not a new phenomenon and point by way of shining example to the founding in 1872 of Yellowstone National Park, seen by environmentalists as a crown jewel of the U.S. National Park system. Notably, Northern Pacific Railroad, which owned land just north of Yellowstone, played a significant role in the establishment of the park. The railroad's motive, however, was not to preserve a unique environmental area, rather it hoped to create a popular (and profitable) tourist attraction for Easterners who would ride their trains to this distant but remarkable scenic wonder. Indeed, the railroad, borrowing an idea from the recently published book by author Lewis Carroll, sold the park as a "Wonderland" to its potential clientele. Before undertaking this initiative, however, the Northern Pacific determined that the area had limited value as a source of precious metals, timber, or grazing land. The profit that could be extracted from Yellowstone, the railroad concluded, would only be realized by making it a national recreational site, which it set out to do. With Congressional passage of a resolution declaring Yellowstone as a 2.2 million acre National Park, Northern Pacific quickly gained approval from Nathaniel Langford, the first Park Superintendent - and a brother-in-law of two of Northern Pacific's largest investors - to extend its track to the park's Gardiner Gateway and to build hotels within the park's boundaries [27].

Exemplary of the more recent push toward green capitalism is the emergence of biofuel production, a development with broad support including that of environmental activists looking to expand sustainable energy consumption and political conservatives concerned about reliance on foreign petrochemicals. In this respect, biofuel production comprises a form of what Ziegler [28] calls 
"nationalistic environmentalism." It is estimated that it requires approximately 10 acres to fuel a car on ethanol for a year. Further, there are significant energy (including oil, natural gas, and other high grade fuels) inputs required. In fact, ethanol production from corn is not truly a renewable energy source because the required use of nonrenewable fossil fuels surpasses levels of ethanol production [29].

Beyond revealing the significant, and often hidden, cost of biofuels, this discussion is of critical importance because the global availability of grain producing land is only about $3 / 10$ of an acre per person and appears to be shrinking under the pressure of biofuel demand [30]. While biofuels are intended primarily to supply transportation demands in wealthy countries this "sustainable" energy source comprises a direct threat to food production and the "sustainability" of the lives of the poor in developing nations. Moreover, demand for biofuel has contributed to the loss of millions of acres of tropical forest, especially in Brazil and Malaysia, as trees are felled to make way for the planting of soy fields for biofuel production [31].

Perhaps the apex of the green capitalist approach to sustaining the environment was unveiled at the 2007 North American International Auto Show in Detroit. At the popular event, General Motors released the first model of its new ethanol-capable Hummer vehicle. Refuting the subsequent harsh comments of critics who note the contradictions of both biofuel production and production of the highly fuel inefficient Hummer, a GM spokesman unperturbedly reported, "We did our own investigation. There is no way we could market a socially irresponsible product" [32]. In fact, there is a long and well documented history of corporations marketing socially irresponsible and often undeniably dangerous products [33].

As this review suggests, capitalist solutions to the contradictions of capitalism comprise a kind of fool's paradise that misdiagnoses both the extent and the ultimate source of the threat facing the ecohealth of Earth and its myriad occupants. The result is an approach to sustainability that rather than producing ecological equilibrium moves us further down the road towards global environmental crises.

\section{Commodification of Nature and the Promotion of Consumption}

One of the core practices of capitalism that puts it on a collision course with environmental sustainability is the transformation of everything in the natural world, including at times people, into commodities for sale on the market. Commodification, which Chernomas and Hudson [34] describe as the privatization of nature and the empowerment of the capitalist at the expense of the collective good, organizes the capitalist approach to the natural environment, beginning with the identification of components of nature that can be assigned an exchange or market value. Under capitalism, as Foster [35] indicates, "the cash nexus has become the sole connection between human beings and nature. With the development of the capitalist division of nature, the elements of nature are reduced to a common denominator (or bottom line): exchange value. In this respect it does not matter whether one's production is coffee, furs, petroleum, or parrot feathers, as long as there is a market."

Realization of the value of a commodity taken from nature in raw or completed form often entails environmental destruction. As Bishop [36] notes, "the market value of the environment may only exist in the destruction of that environment.... minerals and trees often do not have market value except if they can be mined or cut down." Moreover, Bishop stresses, [36] there is tension between the time-scales of capitalism and those of nature: "Business people have short-term horizons, often 
thinking only about this quarter's results. Long-term strategic planning is for five years, or perhaps ten in some industries. Nature knows not this haste. To take a single example, replacing an old growth tree could take up to three thousand years." But, as the case of Yellowstone National Park described earlier suggests, commodification of nature does not only involve extraction of raw materials, it can entail a direct commodification of nature itself as a source of profit. As Silver [37] observes with reference to the U.S., "Our mountains, rivers, deserts and woodlands have suddenly taken on new values as profiteers attempt to package, brand, market and ultimately sell America's Great Outdoors as value-added recreation products." While private corporations have been granted control over visitor concessions in national parks since their founding, in recent years there have been new commodification efforts, such as the push by the American Recreation Coalition (an umbrella group comprised of private-sector organizations supported by the $\$ 400$ billion outdoor recreation industry) to allow increased motorized recreational activity in the national parks despite studies showing the enduring harmful environmental effects of off-road vehicles [38].

Moreover, capitalism is not content to allow the unhurried development of markets for commodities; rather, it is bent, through advertising, on creating markets and expanded consumption. In the case of the commodity known as Yellowstone National Park, for example, the Northern Pacific Railroad aggressively sought to create a market among the wealthy in Eastern cities - those with the disposable cash for distant and even exotic recreation.

The effort to sell Yellowstone as a recreational site was characterized by heavy doses of both nationalism and classism, exemplary of the pragmatic ethics (i.e., whatever works) that guides capitalism advertising. The former theme found expression in exaggerated claims that Yellowstone was a unique national treasure that far surpassed alternative European recreational destinations (e.g., the Alps). The latter theme was given voice in advertising in Harper's magazine and elsewhere that insured would be tourists that during their train ride to the West they would not be exposed to "undesirable company" because only the rich could afford the trip. In a further appeal to elite sensibilities, railroad advertising for Yellowstone emphasized comfort and safety, thereby creating a dynamic tension between the luxury of the accommodations and the raw beauty of the natural commodity being sold [39].

While the themes have changed since the initial marketing of Yellowstone, the approach taken in the contemporary selling of green capitalism and its "environmental friendly" commodities, shows that much has remained the same. Leading the way in this effort was The Body Shop and its promotion of cosmetics. Emphasizing that its products were not tested on animals - evoking harsh images of chemicals being dripped into the eyes of caged dogs and rabbits-The Body Shop sold the message that you could do right by shopping right. At the same time, in its mission statement and in numerous pronouncements by its founder, The Body Shop positioned itself as a caring company that was actively helping to protect the environment and addressing the needs of indigenous peoples around the world. However, critics of the company charged that "the Mexican Indian natives used to illustrate the Body Shop's American Express Campaign were exploited; ... that local producers in the Solomon Islands and the Brazilian Kayapo Indians were left in the lurch [when company needs changed]; [that] in 1996 the Body Shop pulled the plug on a deal to buy shea butter from a town in Ghana, leaving the local economy ....in tatters; [and the company's] foot massagers were made in the Boys Town orphanage in sweat shop conditions" [40]. Moreover, company advertisements focused on the personal benefits of 
expanded consumption, playing heavily on ideal body images and the underlying insecurities and inadequacies of their customers. Criticisms of the company, as well as those of green capitalism generally, were reinforced when The Body Shop was sold for $£ 256$ million to the French cosmetics giant L'Oreal, the very company against which The Body Shop had established its original image as an animal-friendly cosmetics producer.

Beyond efforts to create new markets for new products (or variants of old ones) and thereby continue the core capitalist drive for perpetual growth and rising levels of extraction and consumption, green capitalists, like their non-green predecessors, attempt to shape public policy in the interest of business. Emblematic has been the effort by Whole Foods, Inc.- the world's largest retailer of "natural" and "organic" food products - to influence the national health care debate in the U.S. In an op-ed for the Wall Street Journal, for example (one that was quite similar in content to a piece by the head of the mainstream Safeway, Inc.), Whole Foods co-founder and CEO John Mackey [41] wrote: "Many promoters of health-care reform believe that people have an intrinsic ethical right to health care - to equal access to doctors, medicines and hospitals. While all of us empathize with those who are sick, how can we say that all people have more of an intrinsic right to health care than they have to food or shelter?" Of course, access to food and shelter, no less than health care, have been held up as necessary human rights if we are to avoid a world of food insufficiency and homelessness, yet these are unthinkable positions for a seller of food commodities however green its intended image.

As this discussion suggests, despite incorporating positive elements relative to even less environmentally sensitive expressions of capitalist business practices, even green capitalism — with its continued emphasis on the growth of consumption - is not oriented toward responding meaningfully to the actual implications of the limits-to-growth discourse. If, as some researchers calculate, current global consumption exceeds Earth's ability to replenish resources by 25\% (and growing), then as Rees indicates, all of the sustainability talk of recent years does not suggest an authentic striving for real change but rather "implies that we don't really want to change what we are doing" [42]. There has not, in short, been a serious reconsideration of the commodified capitalist relationship with nature and with the inherent need of a capitalist economy to promote endless growth.

\section{Globalism and Western Style Development}

Commodities, including those based on materials extracted from nature, do not come into existence automatically, rather, they are borne from social processes that are expressions of underlying social relationships. Within capitalism, the global pattern entails the establishment of hierarchical relations in production and consumption between dominant and subordinate nations and, within nations, between dominant and subordinate social classes. Since before the industrial revolution (which significantly increased the pace) this system has organized the global extraction of resources from and befouling of nature to the advantage of dominant nations. Globalization, be it, in Howell's [43] differentiation, "old-style colonialism" or "new-style globalization," involves not only political and economic domination, in varying forms over time and place, or flows of commodities, technologies, and electronic communication, but, as well, the movement of understandings, moral values, and emotionally charged expectations. Such processes, enhanced by reaction against the inequitable structuring of social relations that has characterized the history of globalization, fueled the post-World 
War II push for rapid development in parts of the world that had disproportionately shouldered the social and ecological burdens of past global development but received few of the benefits. Notes Dauvergne [20], "Globalization carries with it underlying values and assumptions about how to best organize the world order.... One core assumption is that indefinite economic growth is possible and necessary - and, moreover, that 'emerging' economies should follow the path of industrial development and intensive agriculture to insure ever more consumption, and thus prosperity and stability. Consuming more per capita is [understood as] a sign that all is well, even when the distribution of its benefits is grossly uneven."

The birth of the development movement as a global initiative among underdeveloped countries dates to the 1955 conference of Asian and African nations at Bandung, Indonesia. As conceived there and afterwards, development is a tripartite project of modernization involving national changes in the economy, a social re-organization, and new governance. The available models for these complex transformations, and the ones heavily touted for many years by economists at the key international lending institutions established by wealthy nations to fund (and control) global development (e.g., World Bank, International Monetary Fund), were those created historically by the wealthy nations themselves. Dibua [44] affirms with special reference to Africa, "it was the economic development theorists that made the boldest and most far reaching attempt at ensuring that economic development in Africa and other non-Western countries resulted in the replication of the Western experience... The project of development was seen not just as catching up with the advanced capitalist of the West, rather, as the replacement of the irrational, backward and traditional economic characteristics of African countries with the rational, modern and ideal type economic features of Western countries." For Rostow [45], for example, this process entailed five "stages of growth" that all economies must pass through on the way to development: traditional society with limited productive capacity; emergence (often through foreign intervention) of the preconditions for economic growth; take-off with continual growth becoming the normal condition of the economy; drive toward maturity with the establishment of a diversified and fully technology driven economy; and arrival of the age of mass consumption. In the last stage, the economy is focused on the ever expanding production of durable consumer goods and services, standards of living rise, and consumption escalates to the level seen in Western developed nations. The environmental contradictions inherent in this fanciful roadmap to prosperity were not part of the postbellum development agenda.

Notably, one of the effects of globalization and the rapid expansion and worldwide diffusion of diverse systems of electronic communication has been an intensified demand for the kinds of consumer goods associated with developed nations. The result has been a "global hurricane of consumption" [20] that has surpassed the growth of the global population. Between 1960 and 2000, for example, while the global population doubled there was a fourfold increase in global expenditures on consumption [20]. As Rees [46] stresses, however, to bring the billions of people in lesser developed nations up to the lifestyle standards of western Europeans would "require ...6 or 7 hectares [about 16 acres] per capita, perhaps 4 or 5 depending on how many assumptions you want to make. The point is on planet Earth right now there are less than 2 hectares per capita of productive land and water." 


\section{Beyond Global Warming: The Emergence of Pluralea Processes}

There is little doubt at this point that global warming is both occurring and that it is primarily driven by ever expanding levels of production and consumption. Further, there is a significant amount of evidence indicating that global warming in its diverse expressions from extreme weather events to rising seas and from droughts to the spread of vector-borne infectious diseases is already causing increasingly severe economic, social, political, and health problems for human communities around the world [1]. Still, as Spratt and Sutton [47] maintain, global change in climatic conditions comprises only the immediately visible "tip of [a] broader global-sustainability iceberg." Beyond global warming the planet and its inhabitants face a disturbingly long list of environmental degradations and emergent ecocrises that no less than global warming are products of capitalist economic growth and related social practices. At the same time that rising planetary temperatures are disrupting the geophysical feedback mechanisms that sustain life on Earth, the planet is also suffering the consequences of air and water pollution, nuclear dumping, acid rain, destruction of wetlands, pesticide and other chemical pollution, deforestation, soil depletion, plastic pollution, exhaustion of edible sea life, a general loss of biodiversity through extinctions, and a significant number of other significant anthropogenic threats. As Jared Diamond [48] asserts, “There are about a dozen major environmental problems, all of them sufficiently serious that if we solved eleven of them and didn't solve the twelfth, whatever the twelfth is, any could potentially do us in." Exemplary of these dramatic threats, it is estimated that as a result of global warming one fourth of all land animals and plants — totaling about one million species_-face extinction by 2050. Further, about half of the forests that existed on Earth at the time of the industrial revolution have been cleared, and the rate of new forest loss is 130 square miles per year. At the current pace of deforestation, tropical rainforests will almost all be gone by 2037 [49]. At the same time, although almost all of the world's food supply comes from the soil, each year about 25 million acres of cropland are degraded or lost to erosion. Efforts to irrigate arid land, in turn, result in damaging salination. Similarly, as a result primarily of rising ocean acidity at least one fourth of coral reefs, atolls, and cays have been eliminated and about half of the rest within three decades face degradation beyond the capacity for recovery [50]. Adverse environmental changes of these sorts have direct impacts on human health and well-being. Already, as Pimentel et al. [51] indicate, because of growth in "air, water, and soil pollutants worldwide, we estimate that $40 \%$ of human deaths each year result from exposure to environmental pollutants and malnutrition."

Even more significant than the number of degradations facing all of the Earth's environments are the consequences of interaction among ecocrises. Instead of viewing the various environmental threats that have arisen as a consequence of capitalist economic growth and development as stand-alone phenomena, it is necessary to examine points of ecocrises intersection as these significantly exacerbate the overall consequences and produce the possibility for catastrophic outcomes for human communities [52].

Elsewhere [53], I have described the multiple intersecting environmental crises we face as pluralea processes, a term derived from the Latin words plur, meaning "many" and alea, meaning risks or hazards. As a result of such intersections, and their potential to generate mutually enhancing effects, Earth's ecosystemic capacity is under severe and growing strain. Illustrative of the kinds of pluralea processes that pose grave risk for human populations are those that impact the quality of the air we 
breathe and lead to as many as two million premature deaths each year worldwide [54]. Currently, as the National Center for Atmospheric Research [55] reports, the thin layer of breathable air that encircles Earth contains multiple pollutants of diverse origins, ranging "from cars on a nearby highway to a forest fire in Alaska to a factory in Asia." Each of these sources of pollution poses grave health risks, but the overall impact is enhanced because of the chemical and systemic interactions that occur among the substances they produce and release into Earth's atmosphere.

One growing source of global air pollution, for example, is the positive feedback loop linking wildfires and global warming. The dryer conditions caused by global warming "favor fire, and more fires release more carbon dioxide from burning vegetation, which in turn favors more warming" [56]. In contributing to both global warming and wildfires, capitalist economic activity plays a critical role in promoting this mutually enhancing and ultimately very dangerous process. As Chris Field [57], a member of the Nobel Prize-winning Intergovernmental Panel on Climate Change, and the founding director of the Carnegie Institution's Department of Global Ecology at Stanford University, warns: "There is a real risk that human-caused climate change will accelerate the release of carbon dioxide from forest and tundra ecosystems, which have been storing a lot of carbon for thousands of years.... It is increasingly clear that as you produce a warmer world, lots of forested areas that had been acting as carbon sinks could be converted to carbon sources... Essentially we could see a forest-carbon feedback that acts like a foot on the accelerator pedal for atmospheric $\mathrm{CO}_{2}$." Wildfires constitute one of the several ways that forests are converted into atmospheric carbon. Since the 1980s, there has been a fourfold increase in the frequency of such fires internationally; while their average size has grown sixfold during the same period. Two of the three most intensive wildfire seasons witnessed during the 56 years that records have been maintained occurred in 2004 and 2005 [58]. Globally, the almost 100,000 wildfires that occurred in 2006 broke existing records both in terms of the number of fires recorded as well as the number of acres, almost ten million, that were consumed by flame. These figures represent a 125 percent increase above average rates recorded over the previous 10 years.

Research in Australia following the bushfires of January to March 2003 that was designed to explore the relationship of daily trends in air pollutants caused by the fire to changes in respiratory outcomes found significant increases in emergency room visits to manage respiratory conditions, including some visits in Melbourne - 125 miles away from the fire front - that were linked to levels of fire-caused particulate matter in the air. Reports Tham et al. [59]: "There are increasing concerns that global warming will increase the frequency and severity of bushfires in the future. Bushfires can produce copious quantities of smoke that often disperse over long distances depending on the climatic conditions, topography and vegetation sources. As a result, smoke may adversely affect communities not directly threatened by fire." One indication of this risk is seen in findings recorded by the European Space Agency's environmental satellite, Envistat, which found that $30 \%$ of the carbon monoxide hovering over Australia during the bushfire season of 2007 had originated 8,000 miles away in forest fires in South America [60].

\section{Eco-nomic Transcendence of the Capitalist Mode of Production}

The emergent discipline of sustainability science focuses on the character of interactions between the environment and human societies and the capacity of humans to direct these interactions along 
sustainable trajectories [61]. Archeological and ethnographic research verifies that while some societies achieve environmental stability and sustainability for millennia, others so deplete local natural resources and so degrade their immediate environment that their social systems are pushed to fragmentation and even collapse. Although debate continues in some cases about the exact causes of depopulation and social breakdown, examples of the latter include the indigenous peoples of what is now the southwestern U.S., the lowland Maya of Central America, the Norse people of Greenland, and the Rapanui, the indigenous inhabitants of Easter Island in the South Pacific [62].

This article has been concerned with the question of whether capitalist society - a rather different order of social complexity with a far greater environmental footprint than the cases cited above-is a sustainable socioeconomic configuration. As suggested by a review of several of its core characteristics and expressions, although capitalism has produced an impressive array of technological innovations, as a global system it is characterized by inherent features that make it unsustainable and, further, that current efforts to implement green modifications to increase sustainability do not really address the central environment-society contradictions of this socioeconomic system.

This conclusion points to the need for an eco-nomic transcendence (derived from the phonetized Greek notion of house or habit, and nómos, law), of capitalist society, that is, the creation, in the wake of the ever widening and interacting ecocrises of capitalism, of an alternative approach to achieving an ecologically sustainable and socially equitable human way of life on Earth. Needed for this initiative is a truly planetary perspective for as Foster [63] indicates, "Sustained economic development over decades ... is ... not the same thing as environmentally sustainable development ...." as the costs of economic growth can be borne by people other than those who reap its rewards.

One alternative approach is democratic ecosocialism, as discussed in the work of activist scholars like Elmar Altvater, John Bellamy Foster, Joel Kovel, and James O'Connor. This orientation to social organization rejects the growth-oriented productivist ethic of capitalism as well as its valuing of possession and consumption as respectable pathways to emotional satisfaction or as markers of personal achievement. Rather, ecosocialism starts with the understanding that we live on a fragile planet characterized by a closed system with limited resources, and that without careful monitoring and control it is quite possible to destroy the foundation of human social existence on Earth. Further, a sustainable society is only achievable as a democratic and justice-based arrangement, as authoritarian social systems tend to be exploitive not only of people but of the environment as well. As a result, the united struggle for sustainability and social and environmental justice offers a context for the forging of the ideas, relationships, and strategies needed for the creation of a viable ecosocialist society [64]. Past experiments with socialism have made clear that attempts under this banner to compete with capitalist production can be as damaging to the environment and human health as capitalism itself. Consequently, the alternative path that is needed must be as committed to long-term environmental sustainability as it is to achieving social equity [1].

\section{Acknowledgements}

Appreciation is extended to Pamela Erickson for her helpful comments on an earlier draft of this paper. 


\section{References}

1. Baer, H.; Singer, M. Global Warming and the Political Ecology of Health: Emerging Crises and Systemic Solutions; West Coast Press: Walnut Creek, CA, USA, 2009.

2. Castro, C. Sustainable development: mainstream and critical approaches. Org. Environ. 2005, 17, 195-225.

3. Brown, H. The Challenge of Man's Future; Viking Press: New York, NY, USA, 1954.

4. Meadows, D. The Limits to Growth: A Report for the Club of Rome's Project on the Predicament of Mankind; Universe Books: New York, NY, USA, 1972.

5. Baer, H. Toward a critical anthropology on the impact of global warming on health and human societies. Med. Anthro. 2008, 27, 2-8.

6. Meadows, D.; Randers, J. Beyond the Limits: Confronting Global Collapse, Envisioning a Sustainable Future; Chelsea Green Publishing Company: Boulder, CO, USA, 1992.

7. von Koerber, E.; Khosla, A; Morley, E. The Concerted Strategies to Meet the Environmental and Economic Challenges of the 21st Century; 2009; Available online: http://www.clubofrome.org/ eng/meetings/Vienna_2009/presentations/FinalCoR.GLOBE.Vienna.Statement.pdf (accessed on 3 September 2009).

8. Barney, G. Global 2000 Report to the President of the United States; Seven Locks Press: Arlington, VA, USA, 1980.

9. Gillman, K. Global Future: Time to Act. Report to the President on Global Resources, Environment and Population; Council on Environmental Quality: Washington, DC, USA, 1981.

10. World Commission on Environment and Development. Our Common Future; Oxford University Press: New York, NY, USA, 1987.

11. Agenda 21. In Proceedings of the United Nations Conference on Environment and Development, Rio de Janeiro, Brazil, 14 June 1992; Available online: http://earthwatch.unep.ch/agenda21/ 30.php (accessed on 1 September 2009).

12. Intergovernmental Panel on Climate Change (IPCC). First Assessment Report; World Meteorological Association: Geneva, Switzerland, 1990.

13. Reducing Risks and Promoting Health Life; World Health Organization (WHO): Vienna, Switzerland, 2002.

14. Moran, E. People and Nature: An Introduction to Human Ecological Relations; Blackwell Publishing: South Malden, MA, USA, 2006.

15. Sample, I. industry leaders denying climate change, says UK Science Minister. 4 March 2009; Available online: http://www.guardian.co.uk/environment/2009/mar/04/manufacturing-climatechange (accessed on 12 October 2009).

16. Escobar, A. Constructing nature: element for a poststructural political ecology. In Liberation Ecologies: Environment, Development, Social Movements; Peet, R., Watts, M., Eds.; Routledge Kegan Paul: London, UK, 1996; pp. 46-68.

17. Pearce, D.; Warford, J. World without End: Economics, Environment, and Sustainable Development; Oxford University Press: New York, NY, USA, 1993. 
18. O'Connor, M. Introduction: liberate, accumulate—bust? In Is Capitalism Sustainable? Political Economy and the Politics of Ecology; O'Connor, M., Ed.; Guilford: New York, NY, USA, 1994; pp. 1-21.

19. Hamilton, C. Growth Fetish; Allen and Unwin: Crows Nest, NSW, Australia, 2003.

20. Dauvergne, P. The Shadows of Consumption: Consequences for the Global Environment; Massachusetts Institute of Technology: Cambridge, MA, USA, 2008.

21. Zencey, E. G.D.P. R.I.P. New York Times, 9 August 2009; Available online: http://www.nytimes.com/2009/08/10/opinion/10zencey.html?pagewanted=1\&_r=1\&adxnnl=1\&a dxnnlx=1261570438-ZWW36trTA7jR/eXZllDfDw (accessed on 1 September 2009).

22. Gellner, E. Nations and Nationalism, 2nd ed.; Cornell University Press: Cornell, NY, USA, 2009.

23. Robbins, R. Anthropologizing economics. Anthro. News 2009, 50, 11-12.

24. Foster, J.B. The absolute general law of environmental degradation under capitalism Cap. Nat. Social. 1992, 3, 77-81.

25. Burkett, P. Marx and Nature: A Red and Green Perspective; St. Martin's: New York, NY, USA, 1999.

26. Esty, D.; Winston, A. Green to Gold: How Smart Companies Use Environmental Strategy to Innovate, Create Value, and Build Competitive Advantage; Wiley: Hoboken, NJ, USA, 2009.

27. Runte, A. Trains of Discovery: Western Railroads and the National Parks; Roberts Rinehart Publishers: Lanham, MD, USA, 1990.

28. Ziegler, A. Biofuels and the rise of nationalistic environmentalism. The Oil Drum, 16 May 2008; Available online: http://www.theoildrum.com/node/3992 (accessed on 2 June 2009).

29. Pimentel, D. Energy and Dollar Costs of Ethanol Production with Corn; Hubbert Center Newsletter \#98-2; M. King Hubbert Center for Petrolium Supply Studies: Golden, CO, USA, 1998; pp. 1-7.

30. Gardner, G. Shrinking Fields, Cropland Loss in a World of Eight Billion; Worldwatch Institute: Washington, DC, USA, 1997.

31. Farigone, J.; Hill, J.; Tilman, D.; Polasky, S.; Hawthorne, P. Land clearing and the biofuel carbon debt. Science 2008, 319, 1235-1238.

32. 2009 Hummer H2 to be ethanol-capable. U.S. News and World Report, 21 March 2008; Available online: http://usnews.rankingsandreviews.com/cars-trucks/daily-news/080331-120367/ (accessed on 22 June 2009).

33. Killer Commodities: Public Health and the Corporate Production of Harm; Singer, M., Baer, H., Eds.; AltaMira/Roman \& Littlefield Publishers: Malden, MA, USA, 2008.

34. Chernomas, R.; Hudson, I. Social Murder and Other Shortcomings of Conservative Economics; Arbeiter Ring Publishing: Winnipeg, Canada, 2007.

35. Foster, J.B. The Vulnerable Planet: A Short Economic History of the Environment; Monthly Review Press: New York, NY, USA, 1994.

36. Bishop, J. Ethics and capitalism: a guide to the issues. In Ethics and Capitalism; Bishop, J., Ed.; University of Toronto Press: Toronto, Canada, 2000; pp. 3-48.

37. Silver, S. The commodification of nature. Available online: http://www.wildwilderness.org/docs/ commod.htm (accessed on 2 September 2009). 
38. Wade, B. A new tragedy for the commons: the threat of privatization to national parks (and other public lands). Georg. Wright For. 2005, 22, 61-67.

39. Mickelson, S. The Northern Pacific Railroad and the Selling of the West: A Nineteenth-Century Public Relations Venture; Pine Hill Press: Freeman, SD, USA, 1993.

40. Heartfield, J. Anita Roddick: prophet of green capitalism. Spiked, 11 September 2007; Available online: http://www.spiked-online.com/index.php/site/article/3815/ (accessed on 22 June 2009).

41. Mackey, J. The whole foods alternative to obamacare: eight things we can do to improve health care without adding to the deficit. The Wall Street Journal, 11 August 2009.

42. Leahy, S. Development: can capitalism be green? IPS News Service, 12 May 2007; Available online: http://ipsnews.net/news.asp?idnews=37712 (accessed on 1 September 2009).

43. Howell, S. The diffusion of moral values in a global perspective. In Globalisation: Studies in Anthropology; Eriksen, T., Ed.; Pluto Press: London, UK, 2003; pp. 198-216.

44. Dibua, J. Modernization and the Crisis of Development in Africa: The Nigerian Experience; Ashgate Press: Surrey, UK, 2006.

45. Rostow, W. The Stages of Growth: A Non-Communist Manifesto; Cambridge University Press: Cambridge, UK. 1956.

46. Gismondi, M. Aurora Online interview with William Rees. Aurora Online, 2009; Available online: http://aurora.icaap.org/index.php/aurora/article/view/18/29 (accessed on 6 November 2009).

47. Spratt, D.; Sutton, P. Climate Code Red: The Case for Emergency Action; Scribe: Melbourne, Australia, 2008.

48. Radford, R. Soil erosion as big a problem as global warming, say scientists. The Guardian, 4 February 2004; Available online: http://citnews.unl.edu/croptechnology/animation/PDF/Science_ conference_article.pdf (accessed on 2 September 2009).

49. Diamond, J. Collapse: How Societies Choose to Fail or Succeed; Penquin: New York, NY, USA, 2005.

50. Curry, P. Ecological Ethics: An Introduction; Polity: Safford, BC, Australia, 2005.

51. Pimentel, D.; Tort, M.; D’Anna, L.; Krawic, A.; Berger, J.; Rossman, J.; Mugo, F.; Doon, N.; Shriberg, M.; Howard, E.; Lee, S.; Talbot. J. Ecology of increasing disease: population growth and environmental degradation. Bioscience 1998, 48; Available online: http://dieoff.org/ page165.htm (accessed on 1 September 2008).

52. Rees, M. Our Final Hour: A Scientist's Warning: How Terror, Error, and Environmental Disaster Threaten Humankind's Future in This Century-On Earth and Beyond; Basic Books: New York, NY, USA, 2003.

53. Singer. M. Beyond global warming: interacting ecocrises and the critical anthropology of health. Anthro. Q. 2009, 82, 795-820.

54. World Health Organization. Air Quality and Health; Available online: http://www.who.int/ mediacentre/factsheets/fs313/en/index.html (accessed on 6 September 2009).

55. National Center for Atmospheric Research. Air quality Research; University Corporation for Atmospheric Research: Boulder, CO, USA, 2004. 
56. U.S. Climate Change Science Program. Thresholds of Climate Change in Ecosystems: Final Report, Synthesis and Assessment. Product 4.2.; U.S. Geological Survey: Reston, VA USA, 2009.

57. Schwartz, M. Global warming damage could be worse than predicted. Stanford University News Service, 18 February 2009; Available online: http://news-service.stanford.edu/news/2009/ february18/aaas-field-global-warming-ipcc-021809.html (accessed on 3 June 2009).

58. Kasischke, E.; William, D.; Barry, D. Analysis of the patterns of large fires in the boreal forest region of alaska. Int. J. Wildland Fire 2002, 11, 131-144.

59. Tham, R.; Erbas, B.; Akram, M.; Dennekamp, M.; Abramson, M. The impact of smoke on respiratory hospital outcomes during the 2002-2003 bushfire season, Victoria, Australia. Respirology 2009, 14, 69-75.

60. European Space Agency. Wildfires in South America lead to carbon monoxide over Australia. Science Daily, 9 May 2007; Available online: http://www.sciencedaily.com/releases/2007/05/ 070509081650.htm (accessed on 8 September 2009).

61. Kates, R.; Clark, W.; Correll, R.; Hall, J.; Jaeger, C.; Lowe, I.; McCarthy, H.; Schellnhuber, H.; Bolin, B.; Dickson, N.; Faucheux, S.; Fallopin, G.; Grubler, A.; Huntley, B.; Jager, S.; Jodha, S.; Kasperson, R.; Magongunje, A.; Matson, P.; Mooney, H.; Moore, B.; O’Riordan, T.; Svedin, U. Sustainability science. Science 2001, 292, 641-642.

62. Sponsel, L. Ecological anthropology. In The Encyclopedia of Earth; Cleveland, C.J., Ed.; Environmental Information Coalition, National Council for Science and the Environment: Washington, DC, USA, 2007; pp. 67-97.

63. Foster, J.B. Ecology against Capitalism; Monthly Review Press: New York, NY, USA, 2002.

64. Foster, J.B. The Ecological Revolution: Making Peace with the Planet; Monthly Review Press: New York, NY, USA, 2009.

(C) 2010 by the authors; licensee Molecular Diversity Preservation International, Basel, Switzerland. This article is an open-access article distributed under the terms and conditions of the Creative Commons Attribution license (http://creativecommons.org/licenses/by/3.0/). 